УДК 371.64:004.4

Литвинова Світлана Григорівна

кандидат педагогічних наук, старший науковий співробітник

Інститут інформаційних технологій і засобів навчання НАПН України, м. Київ, Україна

s_litvinova@i.ua

\title{
ДО ПИТАННЯ ЕКСПЕРТИЗИ ЯКОСТІ ЕЛЕКТРОННИХ ОСВІТНІХ РЕСУРСІВ
}

\begin{abstract}
Анотація. У статті висвітлено науково-методичні підходи до організації експертизи якості електронних освітніх ресурсів (ЕОР) для загальноосвітніх навчальних закладів. Визначено понятійний апарат, описано об'єкт експертизи, уточнено окремі аспекти функцій експертизи, визначено основні завдання, які стоять перед експертизою, узагальнено принципи проведення експертизи (науковість, індивідуалізація, активне включення до навчального процесу тощо), описані вимоги до учасників експертизи ЕОР, обгрунтовано відповідність ЕОР дидактичним і методичним вимогам й описано алгоритм підготовки об'єкта експертизи до визначення відповідності дидактичним вимогам. Встановлено, що експертиза ЕОР спрямована на одержання від експертів відповідних даних і прийняття на їх основі компетентних рішень щодо доцільності використання у загальноосвітніх навчальних закладах.
\end{abstract}

Ключові слова: експертиза; електронні освітні ресурси; принципи; завдання; якість.

\section{1. ВСТУП}

Розвиток інформаційно-комунікаційних технологій, упровадження їх до навчально-виховного процесу, забезпечення навчального простору загальноосвітніх навчальних закладів доступом до мережі Інтернет i навчальним електронним контентом - усі ці процеси зумовили педагогічну спільноту поставити на перший план питання якості електронних освітніх ресурсів.

Постановка проблеми. Упровадження механізмів забезпечення відкритості й доступності електронних освітніх ресурсів, повноти, достовірності й актуальності навчальної інформації, відповідності нормам чинного законодавства, які регламентують їх створення і функціонування, забезпечить навчально-виховний процес загальноосвітніх навчальних закладів якісним навчальним електронним матеріалом, який можна застосовувати на різних етапах уроку й у позаурочний час.

Iз виникненням електронних освітніх ресурсів, які дозволяють керувати груповою, самостійною та індивідуальною роботою учнів на принципово новому організаційному рівні, пов'язані перспективи розвитку нових педагогічних технологій навчання.

Уміння сучасного вчителя застосовувати електронні освітні ресурси у практиці навчання $є$ складовою його компетентності в галузі інформаційних і комунікаційних технологій (ІКТ-компетентності). Для організації навчального процесу вчителю важливо навчитися здійснювати пошук і відбір ЕОР відповідно з реальними потребами для організації інноваційного навчального середовища, визначати доцільність їх використання на різних етапах уроку і проводити оцінювання результатів діяльності учнів із застосуванням ЕОР.

Тому важливим $є$ отримання якісних ЕОР, які будуть підтримувати навчальний процес на новому рівні, створювати інноваційне навчальне середовище, активізувати діяльність учнів і спонукати їх до пошуку нових даних і відомостей про предмет.

Аналіз останніх досліджень і публікацій. Тема оцінювання якості електронних засобів навчального призначення (ЕЗНП) була предметом обговорення круглих столів, 
міжнародних конгресів ЮНЕСКО, різних наукових конференцій, про що зазначають Лаврентьєва Г. П., Лапінський В. В., Шишкіна М. П. [2; 3; 8], питання якості програмних засобів навчального призначення розкрито у працях Бикова В. Ю., Лапінського В. В., Вембер В. П., Жалдака М. І., Морзе Н. В., Тализіної Н. Ф., питання педагогічної експертизи досліджено у працях Леонтьєва Д. О., Солов’я В. В. [4; 6], змістово-методичні показники, дизайн-ергономічність та техніко-технологічність розкрито у працях Роберта В., Вострокнутова I. Е., критерії якості ЕОР для платформ дистанційного навчання визначені Морзе Н. В., Глазуновою О. Г., критерії оцінювання локальних ЕОР описано Литвиновою С. Г. та ін.

Аналіз результатів дослідження свідчить про недостатню вивченість проблеми експертизи електронних освітніх ресурсів.

Мета статті. 3 огляду на це, мета статті полягає в уточненні науковометодичних засад щодо експертизи якості електронних освітніх ресурсів, визначенні завдань, принципів, дидактичних і методичних вимог якості ЕОР та узагальненні технології проведення експертизи.

\section{2. МЕТОДИ ДОСЛІДЖЕННЯ}

Дослідження проводилось у рамках НДР № 0112U000281 «Система психологопедагогічних вимог до засобів інформаційно-комунікаційних технологій навчального призначення» Інституту інформаційних технологій і засобів навчання НАПН України. Під час дослідження використовувались такі методи: аналіз теоретичних джерел 3 проблеми організації i проведення експертизи електронних освітніх ресурсів, узагальнення й оцінювання отриманих результатів.

\section{3. РЕЗУЛЬТАТИ ДОСЛІДЖЕННЯ}

Виклад основного матеріалу. Поняття експертизи в останні роки набуло достатньо широкого використання в педагогічній практиці: експертизи уроку, експертиза дослідно-експериментальної роботи, експертиза інноваційного проекту, авторських програм, підручників, електронних освітніх ресурсів тощо. У різних структурних одиницях формуються багаторівневі системи експертної служби: експертні ради створюються і працюють в окремих освітніх установах (навчальних закладах), у районних органах управління, в інститутах післядипломної педагогічної освіти та ін.

Різноманітність визначень поняття експертизи, неоднозначність тлумачення iіi сутнісних характеристик різними авторами, говорить про різне розумінні іiі місця, функцій, змісту, видів. У низці робіт експертиза розглядається як вид аналітичної діяльності у процесі аналізу об'єкта.

Розглянемо деякі тлумачення поняття «експертиза». Експертиза (від англ. expertise, лат. Expertus - досвідчений, знавець) - розгляд, дослідження експертом-фахівцем якихось справ, питань, що потребують спеціальних знань. У найзагальнішому вигляді експертиза - це спосіб аналізу причинно-наслідкових зв'язків не тільки стосовно того, що вже відбулося, але й того, що очікується, має або може відбутися; це спосіб пізнання певної реальності в тих випадках, коли ця реальність не піддається прямому вимірюванню, обчисленню і взагалі якому завгодно "об'єктивному дослідженню" [1].

Експертиза - розгляд, дослідження якої-небудь справи, якогось питання 3 метою зробити правильний висновок, дати правильну оцінку відповідному явищу [5]. 
У науковій літературі зустрічаються різні види експертизи в освіті. Зокрема: гуманітарна, демократична, атестаційна, експертиза інновацій, психолого-педагогічна. Зважаючи на спільні ознаки об'єкта експертизи в освіті, ми схильні розглядати їх в контексті єдиного поняття, а саме: педагогічна експертиза. Зважаючи на загальне означення експертизи, ми розглядаємо педагогічну експертизу як складну аналітикосинтетичну діяльність, спрямовану на дослідження (перевірку), формування обгрунтованої (вмотивованої) оцінки науково-педагогічного рівня про той чи інший об'єкт(проект) освітньої діяльності [6]. У цілому педагогічна експертиза спрямована на компетентне оцінювання підручників чи посібників, електронного контенту чи електронних освітніх ресурсів тощо. Проведення експертизи спрямоване на одержання від експертів відповідних даних і прийняття на їх основі компетентних рішень щодо об'єкта дослідження.

Визначимо об'єкти експертизи: якість виконання, якість реалізації наукових, методичних, психологічних і педагогічних підходів, перспективність використання EOP.

У дослідженнях окремих аспектів експертизи звертається увага на цілу низку іiі функцій: оцінювання даних про ефективність використання об' єкта; оцінювання якості й отримання колективного судження про об'єкт; підтримка педагогічної ініціативи, узагальнення різних освітніх практик, виявлення інноваційних підходів навчання під час використання об'єкта у педагогічній практиці.

У даний час можна говорити про цілий спектр підходів стосовно визначень поняття експертизи. Експертиза, як різновид процесів наукового пізнання, розглядається не зважаючи на різноманіття трактувань. Від наукових досліджень експертиза відрізняється своїми завданнями: якщо наукові дослідження орієнтовані насамперед на отримання нового знання про об'єкт, то головний зміст експертизи полягає у визначенні якості й установлення відповідності об'єкта педагогічним, навчальним, виховним та розвивальним цілям. Порівняно з моніторингом експертиза менш технологічна, менш орієнтована на норми і стандарти, а більше - на цінності і зміст. Як зазначає Леонтьєв Д. О., експертиза не зводиться до перевірки й оцінки, хоча функція оцінювання експертизи дуже важлива. Істотно відрізняється експертиза і від класичного експерименту: останній обов'язково передбачає вплив на природний хід подій і контроль над "основними змінними"; експертні ж процедури, навпаки, прагнуть мінімізувати втручання [4]. Отже, основними завданнями експертизи є: комплексне дослідження об'єкта; перевірка відповідності об'єкта вимогам державного стандарту, потребам освітнього процесу; оцінювання відповідності об'єкта сучасному рівню наукових, методичних, психологічних та педагогічних вимог; оцінювання рівнів інтерактивності, мультимедійності, відкритості об'єкта; оцінювання перспективності використання об'єкта у педагогічній практиці; підготовка обгрунтованих експертних висновків.

Експертна діяльність переживає етап становлення у сфері освіти, поступово стаючи звичним явищем. Актуальність досліджень в галузі експертизи електронних освітніх ресурсів пов'язана 3 тенденцією стандартизації і систематизації електронного освітнього контенту. Підтвердження цьому - активне обговорення різних аспектів створення і використання електронного контенту у наукових колах Національної академії педагогічних наук України, на колегіях Міністерства освіти і науки, молоді та спорту України, освітніх закладах і виявлення необхідності обгрунтування основ, на яких має будуватися експертиза. Розглянемо принципи побудови експертизи ЕОР:

- науковості, що визначає необхідність використання об'єкта експертизи, який $\epsilon$ підмножиною наукового знання відповідної предметної галузі і максимально сприяє реалізації мети і відповідає цілям навчання; 
- активного включення у навчальний процес вимагає усвідомлення необхідності використання об'єкта експертизи з метою унаочнення навчального матеріалу, підвищення активності й пізнавальної діяльності учнів;

- індивідуалізації, індивідуального підходу в навчанні, що ефективно реалізується під час застосування об'єкта експертизи. Важливим $\epsilon$ визначення індивідуального початкового рівня учнів, сформованості відповідних умінь і навичок.

- принщииии відкритості, доступності, об'єктивності, вірогідності, повноти та точності даних.

Особливої уваги вимагає і кадрове забезпечення експертної діяльності. Учасниками експертизи мають бути фахівці високої кваліфікації, професіонали, а для дослідження діяльності кожного освітнього закладу, через його унікальність, формується відповідна його особливостям експертна група.

Вимоги до учасників експертизи ЕОР: наявність інтересу до проблем розробки і використання ЕОР у навчальних закладах, участь у конференціях, семінарах, виставках; наявність базової ІКТ-компетентності й готовності до використання ІКТ в освітній діяльності; креативність, розвинені творчі здібності, що дозволяють аналізувати проблемні ситуації і знаходити шляхи вирішення протиріч; широта i конструктивність мислення; наукова об'єктивність, аналітичність; наявність інтересу до розвитку інноваційної практики в роботі навчального закладу, відсутність консерватизму; висока виконавська дисципліна, готовність доводити справу до кінця i працювати в команді.

Наукові підходи до проблеми оцінювання якості електронних освітніх ресурсів визначають дидактичні вимоги до ЕОР. Як зазначає Тализіна Н. Ф., упровадження технічних засобів навчання - не самоціль. Їх застосування виправдане тільки в тому випадку, якщо це призводить до підвищення ефективності навчального процесу хоча б за одним з таких критеріїв, як якість навчання, витрати часу і сил викладачем і учнями, фінансові витрати. Якість навчання - головний критерій ефективності навчального процесу [7].

Широке використання EOP у навчальному (навчально-виховному) процесі допускається тільки після проведення його експертизи й отримання позитивного експертного висновку (вимога не поширюється на ЕОР, які створюються для локального використання в межах одного навчального закладу).

3 метою забезпечення високої якості розробки і виконання, ЕОР проходять комплексну експертизу, що включає змістову, навчально-методичну, програмнотехнічну і дизайн-ергономічну складові [2].

Електронні освітні ресурси мають відповідати не тільки стандартним дидактичним вимогам, що пред'являються до навчальних видань (наприклад, до таких як підручники, навчальні і методичні посібники), але й низці специфічних вимог. Дидактичні вимоги відбивають необхідні умови і закономірності процесу навчання, про що зазначає Баврін I. I. Тому дидактичні вимоги до електронних освітніх ресурсів включають такі критерії: науковість, доступність, проблемність навчання, наочність, самостійність, активізація діяльності, системність, послідовність, міцність засвоєння знань, єдності освітніх, розвивальних і виховних функцій навчання, можливість вибору темпу навчання, варіативність навчання, інтерактивність навчання, контроль, коригування дій, розвиток інтелектуального потенціалу [2].

Серед найзначущіших характеристик якості ЕОР можна назвати такі: зміст (у цілому); науковість, відповідність сучасному рівню знань; інформативність; доступність сприйняттю; врахування вікових особливостей; націленість на формування в учнів навичок дослідницької і творчої діяльності; розроблені запитання і завдання, які спонукають до самостійного пошуку додаткових даних і відомостей; якісне художнє 
оформлення; коректність.

Підготовка об'єкта до визначення відповідності дидактичних вимог: подавати навчальний матеріал у систематизованому і структурованому вигляді; враховувати як ретроспективи, так і перспективи формування знань, умінь і навичок під час організації кожної порції навчальної інформації; враховувати міжпредметні зв'язки досліджуваного матеріалу, що відповідають особливостям виду діяльності; ретельно продумувати послідовність подання навчального матеріалу і навчальних впливів, аргументувати кожен крок відносно учня; перевірити логіку побудови процесу здобуття знань, обумовлену змістом навчальних програм; забезпечити зв'язок даних і відомостей, пропонованих електронним освітнім ресурсом, 3 практикою шляхом підбору прикладів, створення змістовних ігрових моментів, завдань практичного характеру, експериментів, моделей реальних процесів і явищ.

Методичні вимоги до ЕОР включають методичні матеріали з предмету, інструкції щодо використання об'єкта, виконання обов'язкових завдань, самостійної роботи, тестів, використання ресурсу в навчально-виховному процесі.

У разі невідповідності дидактичним і методичним вимогам, ЕОР не приймають до подальшого розгляду. Тому, важливим $є$ оприлюднення критеріїв оцінювання ЕОР, розробка методичних рекомендацій щодо підготовки ЕОР до проведення експертизи і проведення апробації на експериментальних майданчиках.

Технологія проведення експертизи включає такі етапи: отримання заяви розробника EOP з проханням проведення експертизи, розробку наказу Міністерства освіти і науки, молоді та спорту України про проведення експертизи (список членів експертної комісії, термін проведення експертизи, перелік базових освітніх закладів для проведення апробації, уточнюються номери контактних телефонів, факсів, електронних адрес); розроблення оцінних листів, інструктивно-методичних матеріалів до складання експертних висновків i заповнення оцінних листів експертними комісіями i загальноосвітніми навчальними закладами; реєстрацію, шифрування, дешифрування об’ єктів (ЕОР) і їх конфіденційність; передачу комплектів об'єктів (ЕОР) головам відповідних експертних комісій, НАПН України для проведення експертизи i загальноосвітнім навчальним закладам для проведення апробації; на вимогу розробника надання матеріалів експертиз; формування пропозицій щодо персонального складу експертної комісії і забезпечення належних умов іiі роботи; формування пропозицій щодо персонального складу апеляційної комісії і забезпечення належних умов іiі роботи; зберігання документації, що стосується експертизи.

\section{4. ВИСНОВКИ ТА ПЕРСПЕКТИВИ ПОДАЛЬШИХ ДОСЛІДЖЕНЬ}

3 метою забезпечення високої якості, ЕОР проходять комплексну експертизу, яка включає змістову, навчально-методичну, програмно-технічну і дизайн-ергономічну складові. Результати комплексної експертизи служать підставою для оцінювання якості EOP.

Експертиза змістового наповнення ЕОР встановлює, передусім, актуальність i відповідність державному освітньому стандарту і навчальній програмі. Відповідність дидактичним і методичним вимогам визначає науково-методичний рівень розробки, інноваційні якості ЕОР. Дизайн-ергономічна експертиза оцінює психологічні, ергономічні та художні якості ЕОР і його компонентів. Програмно-технічна складова визначає працездатність ЕОР програмного продукту і відповідність сучасному технічному рівню аналогічних продуктів; визначає стійкість до помилкових і некоректних дій користувача. Використання EOP у навчальному (навчально- 
виховному) процесі допускається тільки після проведення його комплексної експертизи й отримання позитивного висновку.

Дотримання принципів, виконання завдань спрямовує експертизу якості EOP на одержання від експертів відповідних даних і прийняття на їх основі компетентних рішень щодо доцільності використання у загальноосвітніх навчальних закладах. Компетентний склад експертної комісії і критеріальне оцінювання ЕОР гарантує якість висновків, проте процес апробації у навчальних закладах вимагає розробки відповідної технології проведення, додаткового дослідження та уточнень.

\title{
СПИСОК ВИКОРИСТАНИХ ДЖЕРЕЛ
}

1. Ашмарин И. И. Современное звучание гуманитарной экспертизы / И. И. Ашмарин // Экспертиза в современном мире: от знания к деятельности : научное издание / ред. Г.В.Иванченко, Д. А. Леонтьева. - М. : Смысл, 2006. - С. 82-88.

2. Лаврентьєва Г. П. Науково-методичні підходи та інструментарій експертизи якості електронних засобів навчального призначення / Г. П. Лаврентьєва [Електронний ресурс] // Інформаційні технології і засоби навчання. — 2010. — № 5 (19). — Режим доступу : http://www.ime.eduua.net/em.html.

3. Лапинский В. В. Педагогические требования к цифровым образовательным ресурсам / В. В. Лапинский // Современные достижения в науке и образовании : сб. трудов III Междунар. науч. конф. (16-23 сент. 2009 г., г. Тель-Авив (Израиль)). — Хмельницкий : ХНУ, 2009. — С. $163-165$.

4. Леонтьев Д. А. Комплексная гуманитарная экспертиза: методология и смысл / Д. А. Леонтьев, Г. В. Иванченко. - М. : Смысл, 2008. - 135 с.

5. Словник української мови: в 11 томах. - Т. 2. - 1971. - С. 462. - Режим доступу : http://sum.in.ua/s/ekspertyza.

6. Соловей М. В. До питання про поняття педагогічної експертизи та їі нормативно-правових основ / М. В. Соловей. - Режим доступу :

http://archive.nbuv.gov.ua/portal/soc_gum/peddysk/2007_01/solovey.pdf.

7. Талызина Н. Ф. Компьютеризация и программированное обучение / Н. Ф. Талызина // Вопросы психологии. - 1986. - № 6. - С. 43-45.

8. Шишкіна М. П. Якість програмних засобів навчального призначення: підходи до визначення предмету / М. П. Шишкіна // Науковий часопис національного педагогічного університету імені М. П. Драгоманова. Серія №5. Педагогічні науки: реалії та перспективи. - Вип. 22 : зб. наук. праць / за ред. В. П. Сергієнка. - К. : Вид-во НПУ імені М. П. Драгоманова, 2010. - С. 553-557.

Матеріал надійшов до редакиї 01.04.2013 p.

\section{К ВОПРОСУ ЭКСПЕРТИЗЫ КАЧЕСТВА ЭЛЕКТРОННЫХ ОБРАЗОВАТЕЛЬНЫХ РЕСУРСОВ}

\author{
Литвинова Светлана Григорьевна \\ кандидат педагогических наук, старший научный сотрудник \\ Институт информационных технологий и средств обучения НАПН Украины, г. Киев, Украина \\ s_litvinova@i.ua
}

Аннотация. В статье рассматриваются научно-методические подходы к организации экспертизы качества электронных образовательных ресурсов (ЭОР) для общеобразовательных учебных заведений. Определен понятийный аппарат, описано объект экспертизы, уточнены отдельные аспекты функций экспертизы, определены основные задачи, стоящие перед экспертизой, обобщены принципы проведения экспертизы (научность, индивидуализация, активное включение в учебный процесс), описаны требования к участникам экспертизы ЭОР, обосновано соответствие ЭОР дидактическим и методическим требованиям, описан алгоритм подготовки объекта экспертизы к определению соответствия дидактическим требованиям. Установлено, что экспертиза ЭОР 
направлена на получение от экспертов соответствующих данных и принятия на их основе компетентных решений о целесообразности использования в общеобразовательных учебных заведениях.

Ключевые слова: экспертиза; электронные образовательные ресурсы; принципы; задачи; качество.

\title{
TO QUESTION OF QUALITY EXAMINATION OF ELECTRONIC EDUCATIONAL RESOURCES
}

\author{
Svitlana G. Lytvynova, \\ $\mathrm{PhD}$ (pedagogical sciences), senior researcher \\ Institute of Information Technologies and Learning Tools of NAPS of Ukraine, Kyiv, Ukraine \\ s_litvinova@i.ua
}

\begin{abstract}
The article deals with the scientific and methodological approaches to the examination of quality of electronic educational resources (EER) for secondary schools. It was defined conceptual apparatus, described the object of examination, clarified certain aspects of the functions of examination, determined the basic tasks of expertise, summarized the principles of expertise (scientific, personalization, active involvement in the learning process), described the requirements to the participants of EER expertise, grounded EER accordance to didactic and methodological requirements, described an algorithm of preparation for the examination object to determine compliance with the requirements of didactic. It is established that the assessment is aimed to the receipt from the experts of corresponding data and acceptance on their basis of competent decisions about expedience of the use in general educational establishments.
\end{abstract}

Keywords: assessment; e-learning resources; principles; objectives; quality.

\section{REFERENCES (TRANSLATED AND TRANSLITERATED)}

1. Ashmarin I. I. Modern sounding of humanitarian examination / I. I. Ashmarin // Examination in the modern world: from knowledge to activity: scientific edition / red. G. V. Ivanchenko, D. A. Leont'eva. - M. : Smysl, 2006. - S. 82-88. (in Russian)

2. Lavrent'yeva H. P. Scientifically-methodical approaches and tool of examination of quality of electronic facilities of the educational setting / N. P. Lavrent'yeva [online] // Informatsiyni tekhnolohiyi i zasoby navchannya. — 2010. — \#5 (19). — Available from : http://www.ime.eduua.net/em.html. (in Ukrainian)

3. Lapinskij V. V. Pedagogical requirements to the digital educational resources / V. V. Lapinskij // Sovremennye dostizhenija v nauke i obrazovanii: sb. trudov III Mezhdunar. nauch. konf., 16-23 sent. 2009 g., g. Tel'-Aviv (Izrail'). — Hmel'nickij : HNU, 2009. — S. 163-165. (in Russian)

4. Leont'ev D. A. Complex humanitarian examination: methodology and sense / D. A. Leont'ev, G. V. Ivanchenko. - M. : Smysl, 2008. - 135 s. (in Russian)

5. Dictionary of Ukrainian : in 11 volumes. - Tom 2. - 1971. - S. 462. - Available from : http://sum.in.ua/s/ekspertyza. (in Ukrainian)

6. Solovey M. V. To the question about the concept of pedagogical examination and her normativelylegal bases / M. V. Solovey. - Available from : http://archive.nbuv.gov.ua/portal/soc_gum/peddysk/2007_01/solovey.pdf. (in Ukrainian).

7. Talyzina N. F. Computerization and programed teaching / N. F Talyzina // Voprosy psihologii. 1986. — № 6. - S. 43-45. (in Russian)

8. Shyshkina M. P. Quality of programmatic facilities of the educational setting : going near determination of object / M. P. Shyshkina // Naukovyy chasopys natsional'noho pedahohichnoho universytetu imeni M. P. Drahomanova. Seriya \#5. Pedahohichni nauky: realiyi ta perspektyvy. Vypusk 22 : zbirnyk naukovykh prats' / za red. V. P. Serhiyenka. - K. : Vyd-vo NPU imni M. P. Drahomanova, 2010. - S. 553-557/(in Ukrainian) 